\title{
The effectiveness of the implementation and automation of heat pump on public buildings
}

\author{
Artur Trusov ${ }^{1, *}$, and Svetlana Shilkina ${ }^{1}$ \\ ${ }^{1}$ Moscow State University of Civil Engineering, 129337, 26, Yaroslavskoye Shosse, Moscow, \\ Russian Federation
}

\begin{abstract}
This article is devoted to consideration of effectiveness of the implementation and automation of heat pump on public buildings, in particular, at public catering. This article shows the advantages of this equipment compared to other heating systems, as well as the future development of these systems in Russia. The article presents the analysis of prices for the cost of the heating period, analyze the operating parameters of the gas, electric boilers and heat pumps. Also, there is a heat pump automation scheme, which shows the functional relationship of the devices of automation, regulators and actuators, which are controlled heat pump. According to the calculations the authors come to the conclusion that the best is the heat pump.
\end{abstract}

\section{Introduction}

Today, more and more urgently the question of increasing the energy efficiency of residential buildings in Russia arises. There are various ways to increase their energy efficiency, which is usually realized by increasing the efficiency of engineering systems of buildings and structures. Heat supply systems are some of the possible directions of modernization in public buildings. Heat pump system has aroused great interest among specialists, because of it is economy and energy efficiency, reliability and simplicity of technical solutions. Let us consider some of the issues associated with the system work, fields of application and automation of thermal processes. This article describes the use of the heat pump at a public catering.

\section{Heating system analysis}

A heat pump (HP) is a device that provides heat energy from a source of heat to a destination called a "heat sink". Heat pumps are designed to move thermal energy opposite to the direction of spontaneous heat flow by absorbing heat from a cold space and releasing

\footnotetext{
*Corresponding author: trusov.artur@gmail.com
} 
it to a warmer one. A heat pump uses some amount of external power to accomplish the work of transferring energy from the heat source to the heat sink.

Energy efficiency assessment methodology is actively being developed nowadays. Compare the effectiveness of the introduction of the heat pump in relation to other heating systems. Below we present the most popular equipment used for heating: gas boilers, electric heaters and heat pumps. The table 1 provides a comparative analysis of the heating costs for the object, which is located in Leningrad region. The heat consumption of this object is $30 \mathrm{~kW}$.

Initial data: heat demand facility of $300 \mathrm{~m} 2$ (depending on insulation) is $30 \mathrm{~kW}$; water temperature in the heating system must be $35^{\circ} \mathrm{C}$; Minimum flow temperature is $0{ }^{\circ} \mathrm{C}$. For heat the building the heat pump capacity of $36.6 \mathrm{~kW}$ is selected, a power consumption of $6.6 \mathrm{~kW}$, therefore the heat capacity is $30(\mathrm{Q}) \mathrm{kW}$.

Tabel 1. Heating systems analysis

\begin{tabular}{|c|c|c|c|c|}
\hline $\begin{array}{c}\text { Type of } \\
\text { equipment }\end{array}$ & $\begin{array}{c}\text { Capacity/ } \\
\text { smount }\end{array}$ & $\begin{array}{c}\text { Tarrif of the } \\
\text { city }\end{array}$ & $\begin{array}{c}\text { Tarrif of the } \\
\text { village }\end{array}$ & $\begin{array}{c}\text { Equioment } \\
\text { price }\end{array}$ \\
\hline $\begin{array}{c}\text { Electric } \\
\text { heater }\end{array}$ & $31,5 \mathrm{~kW}$ & $\begin{array}{c}3,14 \mathrm{rub} \\
\mathrm{kW} / \mathrm{h}\end{array}$ & $\begin{array}{c}2,3 \mathrm{rub} \\
\mathrm{kW} / \mathrm{h}\end{array}$ & $80000 \mathrm{rub}$. \\
\hline Gas boiler & $3,6 \mathrm{~m}^{3} / \mathrm{h}$ & $\begin{array}{c}5,1 \mathrm{rub} \\
\mathrm{m}^{3} / \mathrm{h}\end{array}$ & $\begin{array}{c}5,1 \mathrm{rub} \\
\mathrm{m}^{3} / \mathrm{h}\end{array}$ & $\begin{array}{c}150000 \\
\mathrm{rub} .\end{array}$ \\
\hline Heat pump & $6,6 \mathrm{~kW}$ & $\begin{array}{c}3,14 \mathrm{rub} \\
\mathrm{kW} / \mathrm{h}\end{array}$ & $\begin{array}{c}2,3 \mathrm{rub} \\
\mathrm{kW} / \mathrm{h}\end{array}$ & $\begin{array}{c}350000 \\
\mathrm{rub} .\end{array}$ \\
\hline
\end{tabular}

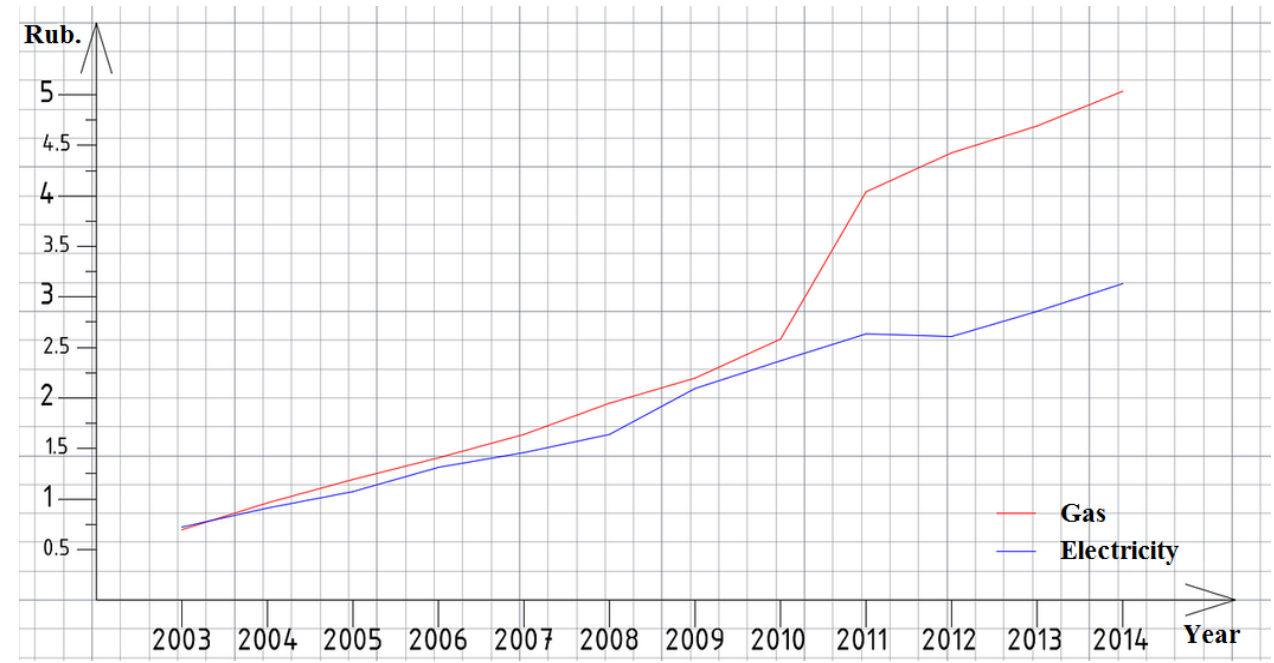

Fig. 1. Electricity and gas cost behaviour analysis

Define the cost of heating. 
The heating period in Russia lasts 7 months, take into account that all the equipment work 7 months, 24 hours per day, at rates which are indicated in Table 1. Thus, we can conclude that now, a relatively cheap form of heating may be carried out using the heat pump, and over the years while maintaining the current trends it will become cheaper and cheaper relative to gas heating.

The costs of heating with an electric boiler is 498 thousand rubles per year at the rate of the city, and 365 thousand rubles at the rate of the village. Expenses with gas boilers is 92 thousand a year. Finally, the cost of heating with a HP will be at 4 thousand for the city and 76000 for the village. Thus, we can conclude that the cheapest equipment for heating is the heat pump, but with the rates of the village. According to forecasts in the next two or three years, heating with heat pump, while the city'c tarrif, will be cheaper. Below is an analysis of the electricity and gas prices for the period 2003-2014. (Fig. 1).

After analyzing the prices of these fuels in the period from 2003 to 2014, we can see that gas prices are rising faster than electricity and this trend will increase year by year. According to forecasts, in 2018 the use of heat pumps will be cheaper than gas boilers.

Consider the heat pump automation scheme (Fig.2)

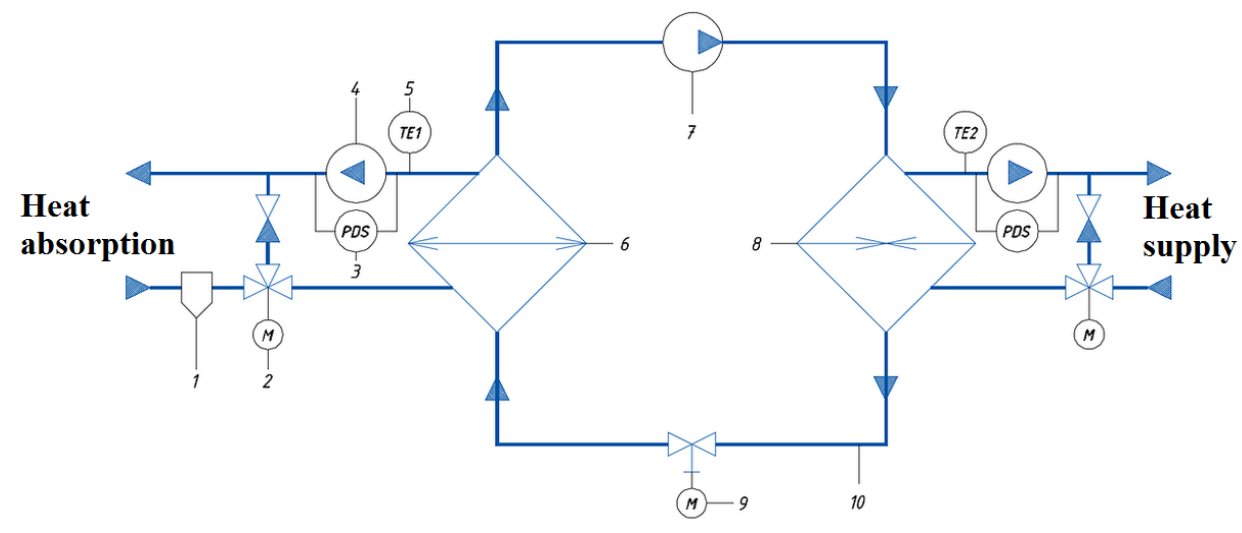

Figure 2. Heat pump automation scheme

Operating principles: the working fluid, in its gaseous state, is pressurized and circulated through the system by a compressor. On the discharge side of the compressor, the now hot and highly pressurized vapor is cooled in a heat exchanger, called a condenser, until it condenses into a high pressure, moderate temperature liquid. The condensed refrigerant then passes through a pressure-lowering device also called a metering device. This may be an expansion valve, capillary tube, or possibly a work-extracting device such as a turbine. The low pressure liquid refrigerant then enters another heat exchanger, the evaporator, in which the fluid absorbs heat and boils. The refrigerant then returns to the compressor and the cycle is repeated.

Since the kitchen and hot shops have great heat radiation, it makes sense to apply heat pumps in these areas (if using air source HP). But it would be better to use HP with heat recovery wastewater. Wastewater temperature of the dishwasher, and other areas of the restaurant reaches 20-25 degrees, which in turn brings greater energy efficiency. Applying such heat recovery scheme, it is possible to save on the expensive installation of geothermal 
analogues. The use of HP in the ventilation system preferably by the fact that it saves on installation of air conditioners, since during the summer HP will work in cooling mode. In addition to these advantages simple automation system should be noted. Below are items included in this system.

Temperature sensors are installed in return coolants to monitor and control coolant in the low grade heat circuit and in the consumer circuit. Differential pressure switches are installed on the pump to monitor their health. Three-way valves are used to control the coolant. These valves are controlled by a PI controller.

\section{Conclusions}

The advantages of heating by using HP are: environmental friendliness ( $\mathrm{CO} 2$ emissions is significantly less than with gas boiler), durability and safety in operation. The service life is 20-25 years, while the life of the gas boiler is 10-15 years. The question arises - why installation of HP in our country is not very popular? Of course, because of the high cost of equipment. In this regard, it is less preferable to gas boilers. But in Europe, this problem was solved by subsidies in favor of the introduction of heat pumps, so that part of the cost of installing HP borne by the State. This reduces the dependency on the use of nonrenewable natural sources of energy, which in turn reduces the amount of $\mathrm{CO} 2$ emissions, and to improve environmental quality.

\section{References}

1. E.S. Bondar, A.S. Gordenco, V.A.Mikcalov, G.V.Nimich, Ventilation and air condition systems' automation, p. 560, (2009)

2. E.M. Belova, Central air condition systems in the building, (2006)

3. S.V. Shilkina, Methodical instructive to make economic part of diploma paper, (2007)

4. A.V. Livchak, M.A. Malachov, S.N.Khorev, Hot shop's ventilation in the public catering, (2007)

5. A. Trusov, S. Shilkina, The effectiveness of implementing automated ventilation system in premises intended for public use, Applied Mechanics and Materials, Advances in Civil and Industrial Engineering IV 